\title{
Anmeldelse: Europæisk menneskeret i dansk og russisk perspektiv
}

\section{Af Henrik Døcker}

Mens danske røster melder om 'forældede' konventioner, vånder russerne sig over alt det nye, internationalismen påbyder dem - som en udfordring mod gode, gamle russiske værdier. To bøger går tæt på disse emner.

Jacques Hartmann: Danmark og den europæiske menneskerettighedskonvention. Ex Tuto 2017, 208 sider. Lauri Mälksoo \& Wolfgang Benedek (eds.): Russia and the European Court of Human Rights - The Strasbourg effect. Cambridge University Press 2018, 418 sider.

Lad os se det i øjnene: uden folkeretten ville verden være kaos, selv om mange - stater såvel som enkeltpersoner - blæser på disse regler. Forvaltningen af reglerne er så noget, både staterne internt og staterne indbyrdes strides om. Netop på menneskerettens område går bølgerne stadig højt ude som hjemme. De går nok højere i og omkring Rusland end i Danmark, men vi har fremdeles noget at lære af hinandens erfaringer.

Den danske jurist Jacques Hartmann, lektor i folkeret ved Dundee universitet, anskueliggør i velskreven form Danmarks brug af den europæiske menneskerettighedskonvention af 1950 og dens tilhørende domstol i Strasbourg. Der er mange myter forbundet med denne domstol, herunder om dens indgriben i rent danske anliggender. Hartmann har sat sig for at gøre op med diverse fejlopfattelser.

Den estiske juraprofessor Lauri Mälksoo og hans østrigske fagfælle, professor Wolfgang Benedek, har redigeret en fremstilling af Ruslands 
livtag med de europæiske menneskerettigheder, som de, før Jerntæppet gik op omkring 1990, ikke havde nogen som helst idé om - eller ikke ville vide af, skal man måske hellere sige. Det er en sørg-munter beretning om høje forventninger og store skuffelser, som tiden efter 2015 har udløst. Rusland har afvist at følge Strasbourg-domstolens afgørelse i en meget stor sag (se nedenfor), og det er ikke tidligere sket i dennes historie.

Prægnant er Hartmanns påpegning af, at den danske kritik af konventionen som 'forældet' er i direkte modstrid med kritikken af domstolens såkaldt dynamiske fortolkning. Denne form for fortolkning, der ligger til grund for de afsagte Strasbourg-domme, er udtryk for, at dommerne retter sig efter den almene opfattelse, ikke mindst på moralens områder, som hersker i dag - ikke den, der var til stede, da konventionen kom til verden for over 60 år siden.

Det nærmeste man kom en beskyttelse af menneskerettighederne inden FN's verdenserklæring og den europæiske konvention fra hhv. 1948 og 1950, er de frihedsrettigheder, der fremdeles findes i den danske grundlov. Men Europa-konventionen introducerede flere rettigheder end grundloven. Eksempelvis dens art. 2, hvorefter 'ethvert menneskes ret til livet er beskyttet ved lov'. Man kan spørge om det betyder noget, når dødsstraf er afskaffet her til lands?

\section{Politisk pres}

En dom fra 2004 viser det: Tyrkiet fandtes at have krænket art. 2, fordi myndighederne i en tyrkisk by ikke havde truffet foranstaltninger til at sikre beboerne mod en gaseksplosion, hvorved 39 mennesker mistede livet. Danmark har endnu ikke haft en sag om art. 2 for Strasbourg-domstolen (Herefter blot: Domstolen). Vi har heller ikke haft sager om art. 3, der forbyder brug af tortur eller umenneskelig eller vanærende behandling eller straf. Imidlertid har Rusland haft et væld af sager, nærmere betegnet 260 domme, vedrørende alvorlige krænkelser af disse to bestemmelser nemlig i forbindelse med de væbnede konflikter i Tjetjenien, dvs. de to tjetjenske krige 1994-96 og 1999.

I de mange forfærdende sager om tortur, 'forsvindinger', henrettelser uden dom, drab på civile ved bombeangreb og straffrihed for de ansvarlige er der i hvert fald blevet betalt godtgørelser af den russiske stat. Landsbynavne som Katyr-Yurt og Kogi (Dagestan) og Beslan vil stå i erindringen om hensynsløse bombardementer og myndighedssvigt ved håndteringen af voldelige træfninger, som gik ud over sagesløse civile.

Det uhyggeligt store antal forsvindinger (over 260 domme herom) foranledigede Domstolen til at fokusere på behovet for skabelsen af et organ, som på én eller anden måde kan løse dette tyngende problem. Det blev kædet sammen med behovet for at udføre retsmedicinske og videnskabelige undersøgelser på relevante steder for at finde, hvor forsvundne kunne være begravet, og i den forbindelse indsamle og opbevare bevismateriale samt identificere personer gennem à jourførte genetiske databanker. 
På et andet punkt: Beskyttelsen af ejendomsretten synes Rusland at have forbedret sig efter nogle domme, hvor borgere ved Strasbourgs hjælp fik udbetalt udbytte fra statsobligationer. Her som i andre postkommunistiske stater, som skulle afvikle statslig ejendom, tog det så også lang tid at få gennemført love, der implementerer afgørelser fra Strasbourg til praktisk gavn for krænkede borgere.

Hvad der i Russia and the European Convention on Human Rights kaldes 'den russiske forvaltningspraksis' tilsiger, - som i mange andre autoritære regimer - at dommere er regeringen følgagtig, dvs. får straffet personer, som sætter sig op mod staten, smidigg $\varnothing r$ 'omfordeling' af offentlige goder til magtens mænd og deres lakajer og i det hele taget holder disciplin i 'det klientilistiske netværk'. Eller som en dommer ved Ruslands almægtige forfatningsdomstol har formuleret det: Min domstol her ville ophøre med at eksistere, hvis dommerne ikke tog hensyn til 'nutidens politiske realiteter'.

Den tidligere retspræsident for Den Europæiske Menneskerettighedsdomstol, Luzius Wildhaber, fik mildest talt dette ind på livet, da den russiske ambassadør ved Europarådet mødte op på hans kontor og forlangte, at domstolen udvirkede udlevering af 13 tjetjenere, der var flygtet til Georgien, til Rusland inden 24 timer - hvis ikke, ville domstolen blive gjort ansvarlig for nogle tjetjenske ekstremisters angreb på et teater i Moskva, hvor 850 mennesker blev taget som gidsler (og hvor 169 mennesker omkom. Red.).

Markant har en russisk dom i Kalashnikov-sagen fra 2002 ligefrem præget europæisk menneskeret. I denne fastslog Strasbourg-domstolen, at det var en krænkelse af art. 3, at fangen Valerij Jermilovitj Kalsahnikov sad $\mathrm{i}$ en celle på $20,8 \mathrm{~m}^{2}$ sammen med 14 andre, dvs. mindre end to $\mathrm{m}^{2} \mathrm{pr}$. person. Den Europæiske Torturforebyggelseskomité (under Europarådet) havde peget på syv $\mathrm{m}^{2}$ som passende. Andre lignende sager påfulgte, og i 2006 vedtog Europarådets Ministerkomité de nugældende europæiske fængselsregler, som har fået stor betydning for indretning af fængsler over hele Europa.

Et par andre russiske sager, illustreret ved Markin- og Zolotukin-dommene for menneskeretsdomstolen, hhv. 2009 og 2012, har drejet sig om ligestilling mellem kønnene og forbuddet mod to gange at blive $\mathrm{d} ø \mathrm{mt}$ for samme forseelse (ne bis in idem), hvorefter retstilstanden i Rusland er blevet forbedret.

\section{Forfatningsdomstol spænder ben}

En tragedie fra fortiden forelagdes forgæves i Strasbourg: Katyn-sagen, hvor pårørende til nogle af de i alt 22.000 polske officerer og andre, der på Stalins ordre blev henrettet i den dengang polske landsby Katyn i 1940, forlangte indsigt i dokumenter om massakren, så meget mere som sovjetiske myndigheder i 1990 havde erkendt ansvaret for udåden. Denne udspilledes imidlertid ti år før den europæiske konvention blev vedtaget, hvorfor Rusland afviste videre kulegravning af dens omstændigheder, og domstolen så sig ikke kompetent til at foretage sig mere. Den konstaterede imidlertid, at de russiske myndigheder ikke havde 
'stillet alle nødvendige midler til rådighed' ved sagens behandling, sådan som art. 38 i konventionen foreskriver.

Bogen om Ruslands forhold til menneskerettighederne - som har form af en antologi med rigtig mange gentagelser - har et naturligt fokus på Yukos-sagen. I denne pålagde Domstolen i 2017 Rusland at betale 1,9 mia. euro i erstatning til det russiske olieselskabs aktionærer, hvilket imidlertid blev afvist af den russiske forfatningsdomstol, som fandt afgørelsen i strid med Ruslands forfatning.

Indtil da havde diverse russiske domstole og eksperter vist respekt for konventionen og Domstolen. Aktionærerne har imidlertid fremdeles en anden erstatningssag mod Rusland verserende ved en voldgiftsdomstol i Haag. Olieselskabet Yukos blev tvangsopløst, gik konkurs, formelt på grund af gigantisk skattegæld, reelt fordi direktøren Mikhail Khodorkovsky (der siden idømtes ti års fængsel) satte sig op mod Vladimir Putin.

Stemmeret for strafafsonere er ikke noget alle Europarådslande kan kapere - Rusland har således gjort Storbritannien følge i sin afvisning heraf. Igen er det den russiske forfatningsdomstol, som modsætter sig en afgørelse fra Strasbourg-domstolen, nemlig i sagen Anchugov \& Gladkov. Den nuværende præsident for Domstolen, Guido Raimondi, opretholder imidlertid et pres på Rusland om ved lovændring at komme på linje med det store flertal af Europarådslande.

Rusland har derudover udfordret hele sit medlemskab af Europarådet ved at tilbageholde i alt 44 mio. euro (eller 15 pct. af budgettet) som medlemsbidrag til rådet. Det samme som en anden inkarneret menneskeretskrænker Tyrkiet i øvrigt har gjort. Rådet fortsætter dog - tilsyneladende upåvirket - sit arbejde. Der opretholdes en dialog med Rusland, hvor adskillige fremtrædende jurister i løbet af Ruslands 20-årige medlemsperiode af rådet dog har udtrykt megen respekt for dettes virksomhed. Den magtfulde forfatningsdomstols tilkendegivelser om kun at respektere Strasbourg-domme, der ikke krænker den russiske forfatning, har imidlertid formørket troen på, at fremtidige domme vil blive efterlevet.

Tilbage til bogen om Danmarks forhold til menneskeretskonventionen er det værd at fremhæve Hartmanns påpegning af, at formålet med menneskerettighederne er at begrænse regeringers og parlamenters handlefrihed og kompetencer for at beskytte borgernes friheder. Domstolens overvågning af lovgivningen (og domspraksis, kan man tilføje. Red.) er derfor ikke en illegitim indskrænkning af demokratiet, men en nødvendig garanti mod tyranni. Han går så vidt som til at sige: I den forbindelse skal domstolene - nationale som internationale - ikke være tro mod Folketinget eller flertallet som sådan. Den rette forståelse af magtens tredeling er, at ingen af de tre magter umiddelbart står over nogen af de andre. De har imidlertid forskellige beføjelser.

\section{Forsvindinger og udvisninger}

Danmark har ikke hidtil haft nogen vanskeligheder med at følge de forholdsvis få sager, hvor Domstolen har 
konstateret dansk brud på konventionen. Hvordan man eventuelt kan påvirke Domstolens retspraksis, har været nævnt i debatten, ligesom det har været kritiseret, at det nærmest er umuligt at ændre ordlyden af enkelte menneskeretsregler i indskrænkende retning - tillægsprotokollerne til konventionen er alle udtryk for en udvidelse af menneskerettighederne i positiv retning.

Hartmann gør opmærksom på, at Danmark - som de øvrige 46 Europarådslande - kan øve indflydelse på Domstolen ved at 'intervenere' $i$ andre landes sager, nemlig ved at regeringen fremsætter synspunkter på disse. Den danske dommer Jon Fridrik Kjølbro har direkte opfordret til, at Danmark benytter sig af denne ret.

Det er sjældent, at Domstolen har hindret udvisning af kriminelle udlændinge fra enkelte Europarådslande. Den heftige danske debat om Levakovic-sagen har fordrejet et sagligt overblik over emnet: Siden 2010 er over 10.000 mennesker i Europarådsrådets medlemskreds blevet udvist ved dom; Danmark udviser hver år hundreder af personer. Reelt anvender Domstolen det subsidiaritetsprincip, som også blev påpeget i den erklæring, der påfulgte den europæiske embedsmandskonference i København i april 2018, og som tilsiger anerkendelse af nationale skøn i vidt omfang. Hartmann, hvis fremstilling generelt har karakter af en yderst overskuelig grundbog, gør en del ud af dette emne.

Menneskeretsbeskyttelsen i Strasbourg vedrører i alt omkring 30 nærmere definerede rettigheder, hvis ræk- kevidde udvides gennem domme. Et mindre antal har vedrørt politisk set 'varme kartofler'; de fleste er helt nede på jorden. De få danske sager har bl.a. vedrørt 'retfærdig rettergang': i Hauschildt-sagen retten til ikke af samme dommer både at få forlænget en række fængslingsfrister og den endelige dom; urimelig lang sagsbehandling som fx da en Kurt Nielsen måtte vente otte år på erstatning for en bilulykke, eller James Valentin, som måtte vente 17 år på at få en konkurssag færdigbehandlet.

Men Danmark har også anvendt konventionen uden forebringelse i Strasbourg, som fx da Niels Holck efter en landsretsdom ikke kunne udvises til Indien på grund af dansk frygt for, at han ville blive underkastet tortur i indiske fængsler. Uden i øvrigt at tage stilling til den alvorlige anklage mod ham for våbennedkastninger over Vestbengalen.

Det er svært at undgå den konklusion, at Strasbourgs beskyttelsessystem er bedre end sit rygte. Hvis man virkelig vil have indsigt $i$, hvad der udrettes, kan det anbefales at stikke næsen ned i den årsrapport, som Europarådets Ministerkomité (de 47 udenrigsministre) udgiver om 'overvågningen af gennemførelsen af domme og afgørelser fra Menneskeretsdomstolen' seneste udgave havde den lange titel: Supervision of the Execution of Judgments and decisions of the European Court of Human Rights 2017 - 11th Annual Report of the Committee of Ministers. Mange oplysninger kan dog også findes på nettet. 